\title{
ДОСЛІДЖЕННЯ ПРОЦЕСІВ УТИЛІЗАЦІї ТЕПЛА ПАРОПОВІТРЯНИХ СУМНШЕЙ: ЛАБОРАТОРНА УСТАНОВКА, ВИМІРЮВАНІ ЗМІННІ, АВТОМАТИЗАЦІЯ ЕКСПЕРИМЕНТІВ
}

\author{
Ковальчук Д.А. ${ }^{1}$, Мазур О.В. ${ }^{2}$, Гудзь С.С. ${ }^{3}$ \\ 1,2,3 Одеська національна академія харчових технологій \\ ORCID: ${ }^{1}$ 0000-0003-0549-5244 \\ E-mail: ${ }^{1}$ radiolomaster@gmail.com, ${ }^{2}$ mazur.av.ua@gmail.com
}

Copyright (C) 2018 by author and the journal "Automation technologies and business - processes. This work is licensed under the Creative Commons Attribution International License (CC BY). http://creativecommons.org/licanses/by/4.0

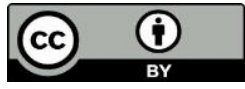

ONAFT

Open Access

DOI: $10.15673 /$ atbp.v10i1.874

У статті розглянуті деякі иляхи підвищення енергоефективності виробництва. Обтрунтовано актуальність $i$ необхідність застосування систем, щзо дозволяють утилізувати тепло пароповітряних сумішей як енергетичних відходів. Розглянуто різні варіанти утилізації $i$ виділені їх недоліки. Запропоновано можливість застосування теплового насоса для більш глибокої утилізації тепла пароповітряних сумішей. Описана конструкція автоматизованого робочого місия дослідника процесів утилізації тепла пароповітряних сумішей, яке дозволить проводити попередні дослідження перед побудовою систем утилізації для конкретного технологічного процесу. Автоматизоване робоче місие включає в себе технологічну систему, шзо дозволяє імітувати пароповітряну суміш із заданими параметрами, проводити утилізацію ї̈ теплової енергії. Глибока утилізація досягається за рахунок застосування в системі теплового насоса «вода-вода». Система обладнана датчиками, щчо дозволяють вимірювати значення всіх параметрів, щзо иікавлять $і$ виконавчими пристроями. Також автоматизоване робоче місце включає програмне забезпечення, яке працює на персональному комп'ютері, і дозволяє управляти ходом експерименту, як в ручному, так і в автоматичному режимі, реєструвати всі дані. При проведенні автоматизованого експерименту усі змінні стабілізуються, окрім однієї, яка змінюється по заданому закону. Наведені результати експериментів, по дослідженню режимів роботи випарника, виконаних в автоматичному режимі. Результати представляють собою сімейства квазістатичних залежностей змінних процесу. Проведено аналіз результатів експериментів. Зроблено висновки за результатами експериментів й розглянуті шляхи вдосконалення системи керування випарником.

The article considers some ways to increase energy efficiency of production. The urgency and necessity of systems application that allow to utilize the heat of steam-air mixes as energy wastes is substantiated. Different variants of utilization are considered and their disadvantages are highlighted. The possibility of using a heat pump for a deeper heat utilization of steam-air mixtures is proposed. The design of the automated workplace for researching the processes of steam-air mixtures heat recovery is described, which will allow conducting preliminary research before building the utilization systems for a particular technological process. The automated workplace includes a technological system that allows to simulate a steamair mixture with specified parameters, to utilize its thermal energy. Deep utilization is achieved through the use of "waterwater" heat pump. The system is equipped with sensors, which allow measuring the values of all parameters that are interest, and the executive devices. Also, an automated workplace includes software that runs on a personal computer, and allows you to manage the progress of the experiment, both manually and automatically, to record all the data. In an automated experiment, all variables are stabilized, except for one that varies according to a given law. The results of experiments on the study of the modes of the evaporator performed in the automatic mode are presented. The results represent a family of quasistatic dependencies of the process variables. The analysis of the results of experiments was carried out. The conclusions are based on the results of experiments and ways of improving the evaporator control system are considered. 
http://www.atbp.onaft.edu.ua/

Ключові слова: автоматизоване робоче місие, автоматизований експеримент, дослідження, тепловий насос, утилізація тепла

Вступ

Питання енергозбереження було актуальним завжди, але останнім часом, у зв'язку з постійним зростанням цін на енергоносії, воно стає все більш гострим. В умовах постійної конкуренції підприємства змушені оптимізувати собівартість продукції, що випускається, яка включає і витрати енергії на іiї випуск. Все це змушує промислові підприємства все частіше замислюватися про впровадження систем, що дозволяють знижувати питомі витрати енергії на одиницю готової продукції.

Огляд літературних джерел

Багато технологічних процесів супроводжуються утворенням великої кількості енергетичних відходів, які в більшості випадків просто викидаються в навколишнє середовище. Енергетичні відходи (ЕВ) - це різниця між енергією, що надходить в технологічний агрегат і корисно використовуваної енергією [1, 3]. Одним 3 видів енергетичних відходів, що найбільш часто зустрічаються є пароповітряні суміші (ППС) 3 різними домішками, які використовуються для ведення технологічного процесу, або утворені в його ході. До прикладів таких ЕВ можна віднести:

- Продукти згорання органічного палива;

- Відпрацьовані сушильні агенти;

- Пароповітряні суміші систем кондиціонування повітря;

- Пароповітряні суміші з технологічних агрегатів при реалізації теплових і тепломасообмінних процесів в різних галузях харчової та хімічної промисловості.

Підвищення ефективності роботи таких технологічних процесів можливо за рахунок утилізації тепла їх енергетичних відходів. Утилізовану енергію можна використовувати повторно в технологічному процесі, або на інші потреби підприємства, такі як опалення або гаряче водопостачання $[2,8]$.

Доцільність застосування системи утилізації тепла пароповітряної суміші на конкретному технологічному процесі потрібно аналізувати, виходячи з таких параметрів як: кількість утвореної ППС, пї температура, вологість, забрудненість домішками.

У найпростішому випадку, для утилізації тепла ППС можуть використовуватися теплообмінники різної конструкції. Найбільшу кількість енергії можливо утилізувати при конденсації водяної пари, що входять в ППС, для чого необхідно охолодити ії нижче точки роси $[4,6]$. Часто на підприємстві відсутні теплоносії 3 досить низькою температурою, для здійснення такого теплообміну. В [5] була розглянута можливість застосування теплового насоса для глибокої утилізації тепла димових газів в котельні. Застосування теплових насосів з метою утилізації їх теплової енергії можливо і може бути досить ефективним для будь-якого технологічного процесу, де має місце викид пароповітряних сумішей як енергетичних відходів,.

\section{Основна частина}

Розробка теплонасосної систем глибокої утилізації енергії ППС вимагає проведення попередніх досліджень, для оцінки можливості ефективного використання вторинних енергоресурсів, пошуку оптимальних режимів роботи, дослідження процесів утилізації тепла, як об'єкта управління, синтезу і налагодження енергоефективних алгоритмів управління. Для таких досліджень було розроблено та виготовлено лабораторну установку - автоматизоване робоче місце (AРМ) дослідника процесів утилізації тепла пароповітряних сумішей, яка дозволяє проводити експерименти, як в ручному, так і в автоматичному режимі, налагоджувати алгоритми управління.

АРМ дослідника включає в себе технологічну систему, вимірювальні пристрої, виконавчі механізми, електронну систему збору даних та управління, персональний комп'ютер.

Схема технологічної системи показана на рисунку 1. Вона складається з наступних основних вузлів: генератора пароповітряної суміші (ГППС), конденсаційного утилізатора тепла (КУТ), теплового насосу (ТН) класу «вода-вода» та допоміжного обладнання. На схемі показано взаємозв'язок між технологічними вузлами установки, розташування всіх датчиків і виконавчих механізмів.

ГППС імітує пароповітряну суміш, теплову енергію якої необхідно утилізувати, за температурою та вологістю і дозволяє змінювати їх. До складу цієї секції входить теплообмінник-зволожувач контактного типу (1), що підігріває повітря та зволожує його до 100\% відносної вологості насичуючи його необхідною кількістю водяних парів, ємність 3 гарячою водою (23), що підігрівається електричним нагрівачем, циркуляційний насос (24) зі змінною продуктивністю, електричний перегрівач повітря (3). Повітря на виході з цієї секції за своєю температурою, та вологовмістом емітує димові гази. Вологовміст повітря можливо змінювати, змінюючи температуру повітря на виході теплообмінниказволожувача, оскільки вона буде мати 100\% абсолютну вологість, і відповідний ій вологовміст. За допомогою електричного перегрівала досягається необхідна температура пароповітряної суміші. 


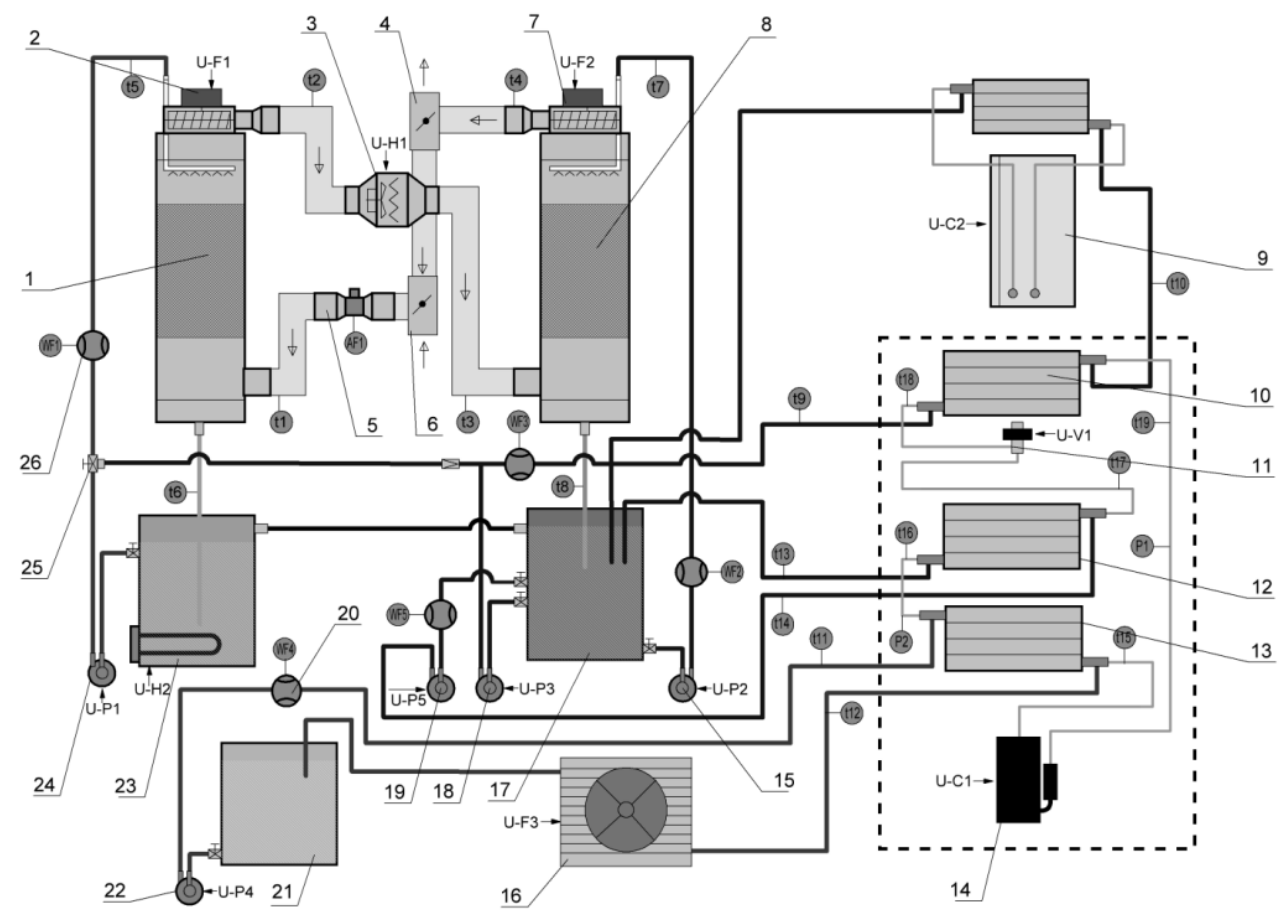

Рисунок 1. Технологічна схема установки.

1 - теплообмінник-зволожувач контактного типу, 2, 7 - вентилятори циркуляції ППС, 3 - перегрівач повітря, 4, 6 заслінка, 5 - витратомір ППС, 8 - конденсаційний теплоутилізатор, 9 - додатковий тепловий насос, 10 - випарник ТН, 11 - ЕРВ, 12 - переохолоджувач холодоагенту ТН, 13 - конденсатор ТН, 14 - компресор ТН, 15, 18, 19, 22, 24 циркуляційні насоси, 16 - радіатор охолодження конденсатора, 17 - ємність з охолоджуючою водою, 20, 26 витратоміри води, 21 - ємність води контуру конденсатора, 23 - ємність підігріву води, 25 - трьохходовий вентиль.

У КУТ відбувається відбір тепла від пароповітряної суміші. До складу цієї секції входить конденсаційний теплообмінник (8), крізь який проходить пароповітряна суміш від ГППС та охолоджена вода, ємність 3 охолодженою водою (17), яка охолоджується тепловим насосом, циркуляційний насос (15) зі змінною продуктивністю.

Тепловий насос «Вода-Вода» забезпечує відбір тепла від КУТ з метою їі утилізації. До його складу входять компресор з регульованою продуктивністю (14), конденсатор (13), переохолоджувач холодоагенту (12), випарник (10), електронний розширювальний вентиль (ЕРВ) 3 електроприводом (11). Циркуляційні насоси зі змінною продуктивністю забезпечують циркуляцію теплоносія через теплообмінники. Двигун компресора живиться від перетворювача частоти (ПЧ), який дозволяє змінювати частоту його обертання від 2000 до 4000 об/хв, змінюючи тим самим продуктивність компресора.

Застосування ЕРВ в мікрошаговому режимі (до 9600 кроків на діапазон) дає можливість 3 високою точністю змінювати режим роботи випарника в широкому діапазоні робочих температур. Чисельно величина перегріву визначається як різниця між температурою пари на виході випарника, і температурою кипіння холодоагенту, яка визначається тиском в випарнику. За величиною перегріву можна судити про заповнення випарника киплячим холодоагентом. У разі, якщо в випарник надходить недостатньо холодоагенту, кипіння буде відбуватися не по всій його довжині, в частині випарника відбуватиметься перегрів вже холодоагенту, що випарувався. Оскільки максимальний відбір тепла відбувається при кипінні холодоагенту, та частина випарника, де буде рухатися газоподібний холодоагент, по суті, не буде працювати. Наявність перегріву говорить про те, що весь холодоагент надійшов у випарник перейшов в газоподібну фазу.

Допоміжне обладнання установки включає: додатковий тепловий насос «вода-повітря» (9), який охолоджує воду в ємності (17), у випадку якщо продуктивності основного ТН недостатньо, радіатор 3 вентилятором (16), для охолодження води в контурі конденсатора та стабілізації ії температури або тиску конденсації основного ТН.

Комплект обладнання дозволяє формувати та досліджувати процеси утилізації пароповітряних сумішей з заданими вологовмістом в діапазоні від 5 до 300 г/м3 та температурою в діапазоні від 5 до $150{ }^{\circ} \mathrm{C}$. Можливий діапазон Зміни витрат ППС - від 20 до 200 м3/год.

Електронна система збору даних та управління (СЗДУ) складається з керуючого мікроконтрлера, датчиків для вимірювання технологічних параметрів та виконавчих пристроїв. Структурна схема СзДУ показана на рисунку 2. Мікроконтролер виконує опитування усіх датчиків, зберігає їх показання у внутрішній пам’яті, виконує усі необхідні 
обчислення, керує роботою виконавчих пристроїв. СЗДУ має пульт місцевого керування, за допомогою якого можна оперативно получити показники любого датчика, а також змінити будь який керуючий вплив, або завдання на рівень його підтримання.

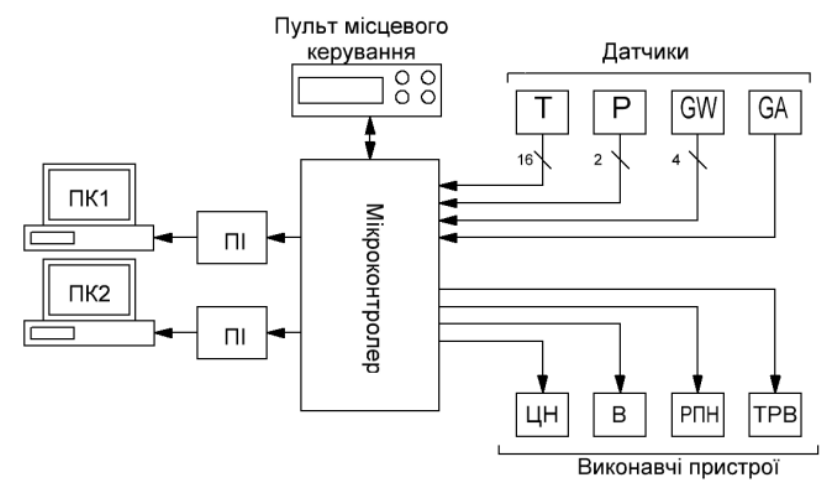

Рисунок 2. Структурна схема СЗДУ

Датчики що входять до складу установки.

T1-T19 - цифрові датчики температури DS18B20, з діапазоном виміру $-50-+150{ }^{\circ} \mathrm{C}$ (див. рис. 1). Серед них:

- $\quad \mathrm{t} 1$ - температура повітря на вході ГПВС;

- $\quad \mathrm{t} 2$ - температура ПВС на виході зволожувача ГПВС;

- $\quad$ t3 - температура ПВС на вході КУТ;

- $\quad$ t4 - температура ПВС на виході КУТ;

- $\quad$ t5 - температура води на вході в ГПВС;

- $\quad$ t6 - температура води на виході з ГПВС;

- $\quad \mathrm{t} 7$ - температура води на вході в КУТ;

- $\quad$ t8 - температура води на виході з КУТ;

- $\quad$ t9 - температура води на вході у випарник ТН;

- $\mathrm{t} 10$ - температура води на виході з випарника ТН;

- $\quad \mathrm{t} 11$ - температура води на вході в конденсатор ТН;

- $\quad$ t12 - температура води на виході з конденсатора ТН;

- $\quad \mathrm{t} 13$ - температура води на вході переохолоджувача холодоагенту ТН;

- $\quad$ t14 - температура води на виході з переохолоджувача холодоагенту ТН;

- $\quad$ t15 - температура холодоагенту на вході в конденсатор ТН;

- $\mathrm{t} 16$ - температура холодоагенту на виході $з$ конденсатора ТН;

- $\quad \mathrm{t} 17$ - температура холодоагенту на виході з переохолоджувача ТH;

- $\quad \mathrm{t} 18$ - температура холодоагенту після ТРВ, що надходить у випарник ТН;

- $\quad \mathrm{t} 19$ - температура холодоагенту на виході з випарника ТН.

P1-P2 - цифрові датчики тиску, з діапазоном вимірювання 0-30 атм.

- $\quad$ Р1 - тиск на випарнику;

- $\quad$ Р2 - тиск на конденсаторі.

WF1-WF5 - крильчасті датчики витрати води з імпульсним виходом. Встановлені у всіх циркуляційних контурах. AF1 - аналоговий калориметрический витратомір повітря 3 діапазоном виміру 0-300 м³/год.

\section{Керуючі впливи в установці.}

- U-P1 - Управління продуктивністю водяного насоса ГПВС;

- $\quad$ U-P2 - Управління продуктивністю насоса КУТ;

- $\quad$ U-P3 - Управління продуктивністю насоса випарника;

- $\quad$ U-P4 - Управління продуктивністю насоса конденсатора;

- $\quad$ U-P5 - Управління продуктивністю насоса переохолоджувача;

- $\quad \mathrm{U}-\mathrm{F} 1, \mathrm{U}-\mathrm{F} 2$ - Управління продуктивністю вентиляторів циркуляції повітря;

- U-F3 - Управління частотою обертання вентилятора скидання тепла конденсатора;

- $\quad \mathrm{U}-\mathrm{H} 1$ - Управління потужністю перегрівача повітря на виході ГПВС (ШІМ);

- $\quad \mathrm{U}-\mathrm{H} 2$ - Управління потужністю електронагрівача води ГПВС (ШІМ);

- $\quad \mathrm{U}-\mathrm{C} 1$ - Управління продуктивністю компресора ТН (частотне управління); 
- $\mathrm{U}-\mathrm{C} 2$ - Управління компресором додаткового охолоджувача води (позиційне керування);

- $\quad \mathrm{U}-\mathrm{V} 1$ - Контроль стану ТРВ (кроковий привід).

\section{Контури регулювання.}

Для забезпечення чистоти експерименту необхідно виключити вплив усіх збурень на досліджувані параметри. В ході експерименту тільки один параметр цілеспрямовано змінюється, і реєструється відгук всієї системи на його зміну. Інші параметри при цьому повинні бути стабілізовані на необхідному рівні. АРМ включає кілька контурів регулювання, завдання яким можливо стабілізувати умови проведення експерименту. До них відносяться:

1. Контур стабілізації вмісту вологи ППС на виході секції зволоження ГППС (датчик t2). Регулювання абсолютного вмісту вологи ПВС здійснюється зміною температури ППС на виході секції зволоження шляхом зміни потужності електронагрівача в ємності 23 (див. рис. 1, керуючий вплив U-H2). Так як повітря в секції зволоження досягає 100\% відносної вологості, абсолютний вологовміст можна визначити по температурі, до якої було нагріто повітря. Управління потужністю електронагрівача здійснюється плавно, за допомогою твердотільного реле.

2. Контур стабілізації температури ППС на виході ГППС (датчик $\mathrm{t3}$ ). Регулювання здійснюється шляхом зміни потужності перегревателя ППС 3 (див. рис. 1, керуючий вплив U-H1).

3. Контур стабілізації температури охолоджуючої води, яка подається в теплоутилізатор. Регулювання здійснюється шляхом зміни частоти обертання компресора теплового насоса, за допомогою перетворювача частоти (керуючий вплив U-C1).

4. Контур стабілізації температури води, що надходить у випарник ТН. Контур працює при дослідженні режимів роботи теплового насоса без системи теплоутілізаціi. В цьому випадку потрібно переключити вентиль 25, i регулювання температури буде здійснюватися зміною потужності електронагрівача 23 (керуючий вплив U-H2).

5. Контур стабілізації температури води, що надходить в конденсатор ТН. Регулювання здійснюється шляхом зміни частоти обертання вентилятор на радіаторі, через який циркулює вода контуру конденсатора (керуючий вплив U-F3).

6. Контур стабілізації перегріву парів холодоагенту у випарнику ТН, для забезпечення максимального завантаження випарника, і запобігання попаданню рідкого холодоагенту в компресор. Регулювання здійснюється шляхом зміни положення електронного розширювального вентиля (ЕРВ).

7. Контури стабілізації витрати у всіх трубопроводах. Регулювання здійснюється шляхом зміни частоти обертання двигунів всіх циркуляційних насосів.

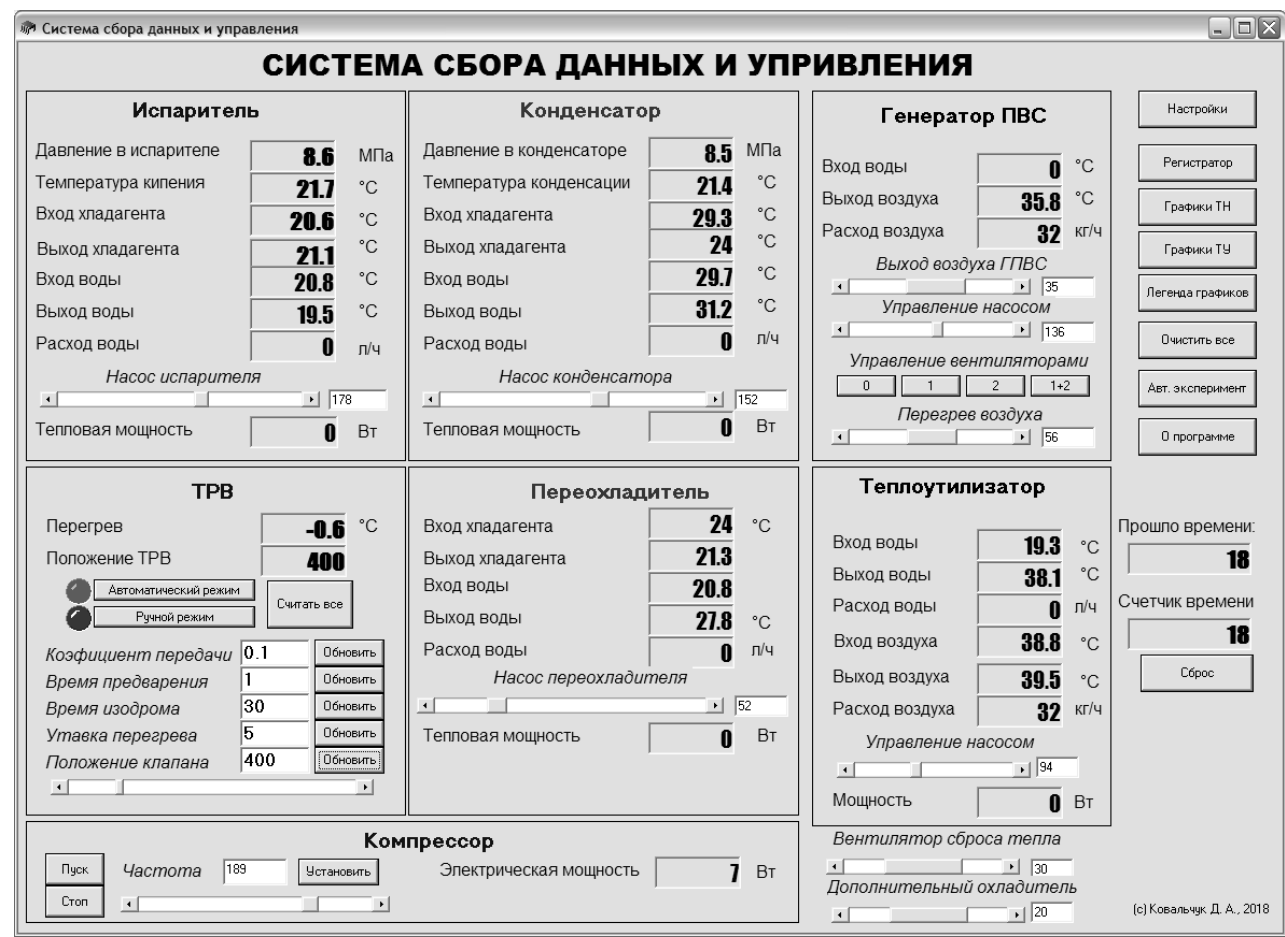

Рисунок 3. Головне вікно програми

СЗДУ з'єднана з двома персональними комп'ютерами (ПК1 та ПК2) через перетворювачі інтерфейсів UART-USB (ПI). На першому комп’ютері працює розроблене програмне забезпечення збору даних та управління (ПзЗДУ), яке 
регіструє усі виміряні сигнали, відображує їх у вигляді графіків, таблиці, має можливість збереження їх у файлі, має можливість автоматичного збереження даних з заданим інтервалом, та дозволяє керувати усіма виконавчими механізмами як в ручному так і в автоматичному режимі, керуючи ходом експерименту. Обмін даними між ПК та СЗДУ відбувається по протоколу з перевіркою контрольної суми кожного переданого параметру. Це значно зменшує ризик передачі хибних даних, в наслідок дії електромагнітних та інших перешкод. На рисунку 3 показано головне вікно ПЗЗДУ. У ньому в реальному часі відображаються показники всіх датчиків, присутні кнопки для керування виконавчими механізмами, контурами регулювання та іншими функціями. На рисунку 4 показане вікно графічного регістратора даних. На рисунку 4 показано вікно табличного регістратора даних, в якому є функція збереження даних в форматі MS Excel, з можливістю автоматичного збереження.

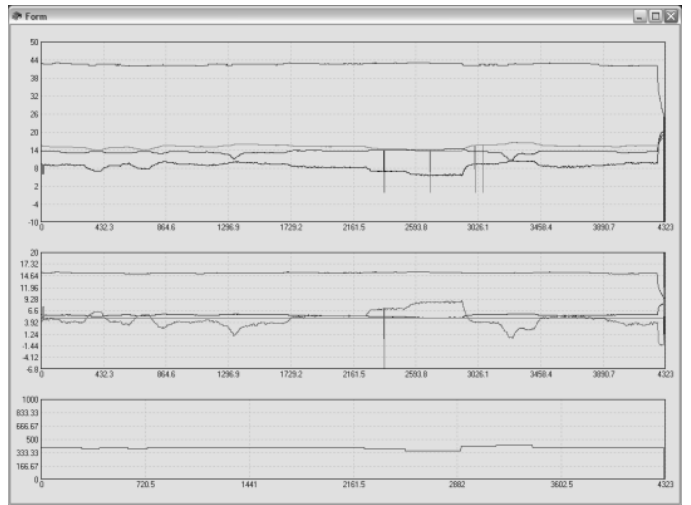

Рисунок 4. Вікно графічного регістратора даних

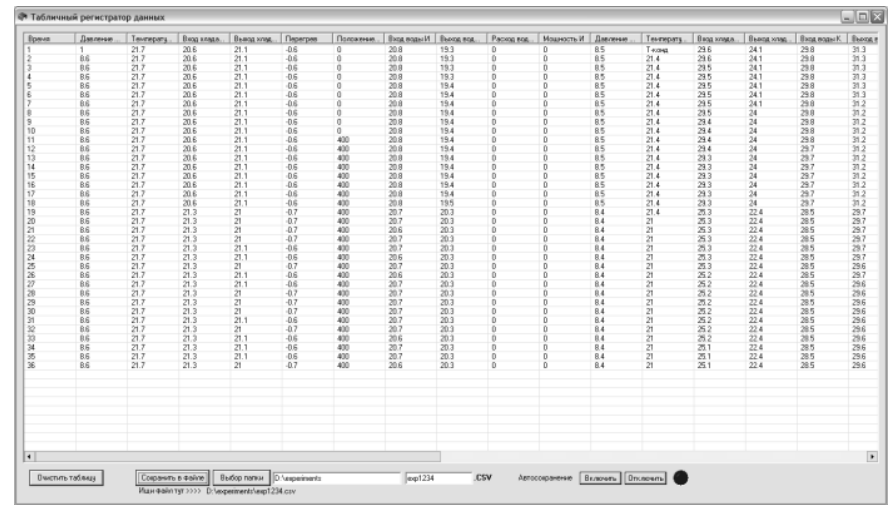

Рисунок 5. Вікно табличного регістратора даних

На рисунку 6 показано вікно керування автоматизованим експериментом. В режимі автоматизованого експерименту один із керуючих впливів ступінчасто змінюється з заданим шагом та інтервалом. Вказується також напрям зміни (збільшення чи зменшення), та кінцеве значення, при якому експеримент буде завершено. За допомогою функції автоматизованого експерименту можливо отримувати квазістатичні характеристики об’єкта по будь яким каналам, із мінімальними витратами людського часу.

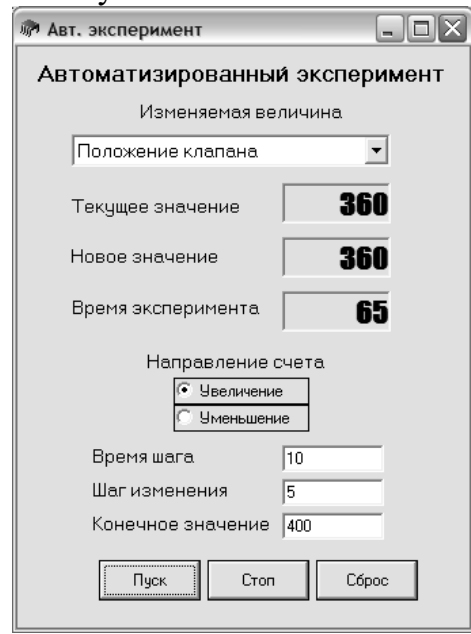

Рисунок 6. Вікно керування автоматизованим експериментом.

\section{Результати експериментів}

На даний момент із застосуванням АРМ виконаний ряд експериментів $з$ дослідження режимів роботи ТН у складі системи утилізації ППС. Були отримані сімейства квазістатичних залежностей параметрів теплового насоса як об'єкта управління по каналу завантаження випарника. Всі експерименти проводилися в автоматичному режимі. Змінним параметром було положення ЕРВ, при цьому інші параметри, такі як температури і витрати води на вході у випарник і конденсатор ТН, частота обертання компресора були стабілізовані. Нижче наведені деякі результати експерименту у вигляді графічних залежностей.

На рисунку 7 показані квазістатичні залежності деяких параметрів ТН від положення ЕРВ в діапазоні від 350 до 470 кроків (з 2400 можливих), при цьому були стабілізовані на рівні $25{ }^{\circ} \mathrm{C}$ i $35{ }^{\circ} \mathrm{C}$ температури води на вході у випарник і конденсатор відповідно, частота обертання компресора на рівні 3000 об/хв, а витрати води через випарник і конденсатор - 300 л/год. 


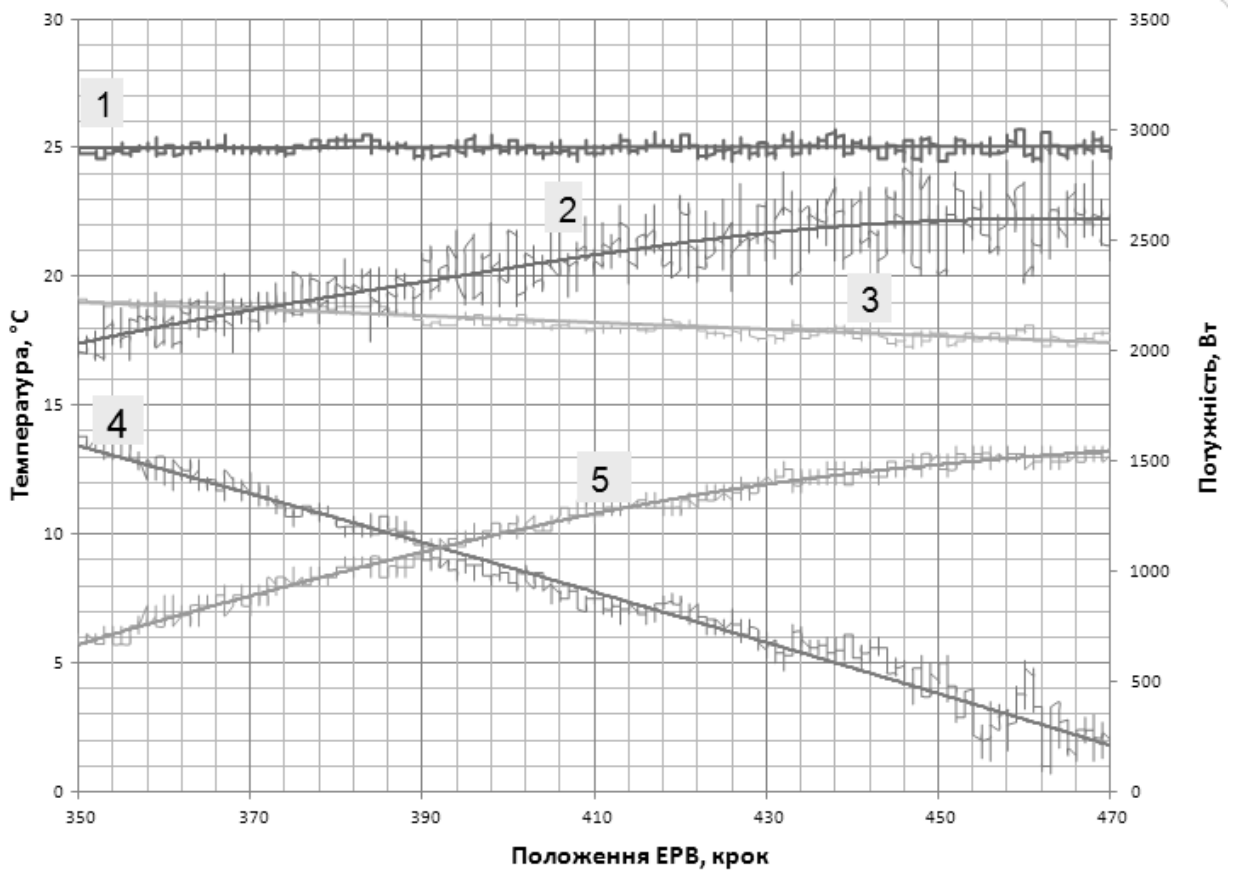

Рисунок 7. Квазістатичні залежності параметрів ТН по каналу керуючого впливу завантаження випарника 1 - Температура води на вході випарника ТН, 2 - Потужність випарника ТН, 3 - Температура води на виході випарника ТН, 4 - Температура перегріву холодоагенту у випарнику ТН, 5 - Температура кипіння холодоагенту у випарнику ТН.

3 представлених на рисунку 7 залежностей видно, що при відкритті ЕРВ спосерігається підвищення тиску у випарнику, а також збільшення його теплової потужності. При цьому, очевидно, зростає й енергетична ефективність ТН. Але при цьому також знижується рівень перегріву парів холодоагенту на виході випарника. При зниженні рівня перегріву нижче $4{ }^{\circ} \mathrm{C}$ збільшується амплітуда його коливань, що може бути пов'язаним 3 попаданням в зону вимірювання температури холодоагенту на виході випарника крапельної фази у зв’язку з приближенням фронту кипіння. Попадання рідкого холодоагенту в компресор може привести до гідроударів і виходу 3 ладу компресора, іншими словами до аварійної ситуації. Очевидно, що найбільш ефективний режим роботи випарника відповідає мінімально можливому перегріву, який забезпечує відсутність рідкої фази холодоагенту на вході компресора, проте в цьому режимі існує висока ймовірність виникнення аварійної ситуації (попадання рідкого холодоагенту в компресор). Залежності рівня перегріву від положення ЕРВ - майже лінійні, практично у всіх режимах роботи випарника.

На рисунку 8 представлено сімейство квазістатичних залежностей по каналу «Положення ЕРВ - Перегрів холодоагенту у випарнику ТН» при постійній температурі води на вході у випарник $20{ }^{\circ} \mathrm{C}$ i при трьох різних температурах води на вході в конденсатор $\left(30^{\circ} \mathrm{C}, 35^{\circ} \mathrm{C}, 40^{\circ} \mathrm{C}\right)$.

На рисунку 9 представлено сімейство квазістатичних залежностей по каналу «Положення ЕРВ - Перегрів холодоагенту у випарнику ТН» при постійній температурі води на вході в конденсатор $35{ }^{\circ} \mathrm{C}$ i при трьох різних температурах води на вході в випарник $\left(20{ }^{\circ} \mathrm{C}, 25{ }^{\circ} \mathrm{C}, 30{ }^{\circ} \mathrm{C}\right)$. Обидва експерименту проводилися при частоті обертання компресора 3000 об / хв і витратах води через випарник і конденсатор - 300 л / год.

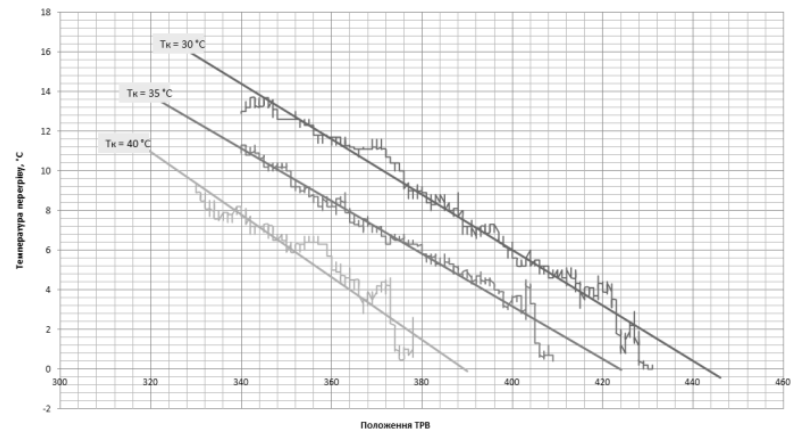

Рисунок 8

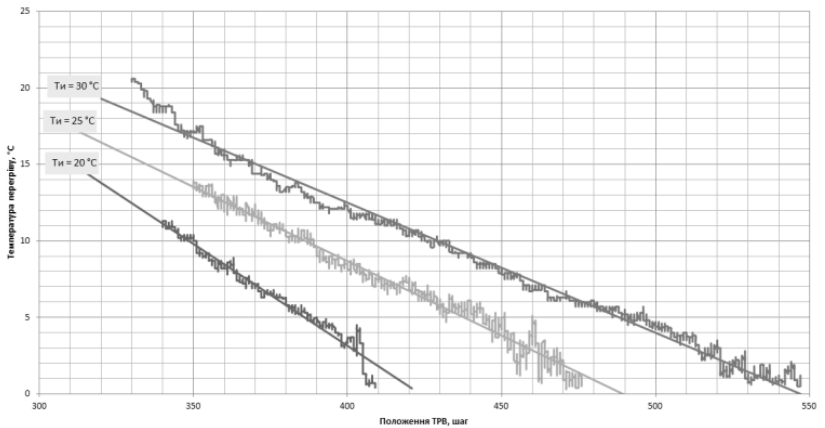

Рисунок 9 
На рисунку 10 представлено сімейство квазістатичних залежностей по каналу «Положення ТРВ - Перегрів холодоагенту у випарнику ТН» при постійній температурі води на вході в конденсатор (в даному випадку $\left.35^{\circ} \mathrm{C}\right) \mathrm{i}$ випарник (в даному випадку $20^{\circ} \mathrm{C}$ ), при різних частотах обертання компресора (50 Гц і 55 Гц).

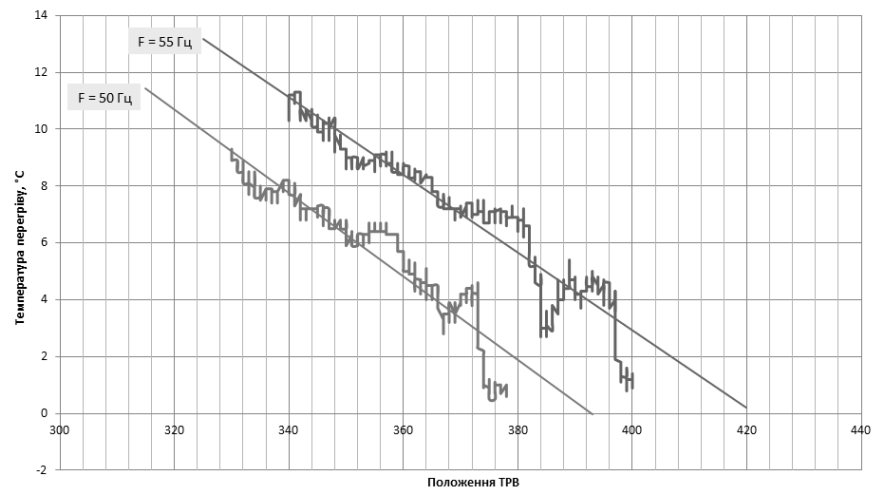

Рисунок 10.

На всіх графіках виведені як дані, отримані безпосередньо в ході експерименту, так і дані отримані в ході лінійної апроксимації результатів експерименту для більш наочного усвідомлення результатів. Аналіз отриманих квазістатичних характеристик показує, що на значення перегріву холодоагенту на виході випарника істотний вплив роблять положення клапана ЕРВ, а також температури води, що надходить у випарник і конденсатор при постійній витраті через них, та продуктивність (частота обертання) компресора.

Вплив положення ЕРВ є найбільш істотним, і найлегше піддається зміні, тому при реалізації САР ця величина буде керуючим впливом. Решта величини віднесемо до контрольованих збурень. 3 результатів експериментів видно, що всі впливи викликають зміщення характеристик. Крім того, зміна температури води, що надходить у випарник також призводить до зміни нахилу характеристики, або коефіцієнта передачі об'єкта по каналу «Температура на вході випарника - перегрів». При зміні температури води на вході випарника від 20 до $30{ }^{\circ} \mathrm{C}$ коефіцієнт передачі змінився майже в 2 рази. У той же час коефіцієнт передачі змінюється незначно при зміні температури води, що надходить в конденсатор.

\section{Висновки}

Розроблене АРМ дослідника дозволяє оперативно дослідити процеси утилізації тепла пароповітряних сумішей 3 широким діапазоном параметрів, таких як вміст вологи, температура витрата. Є можливість дослідження як системи в цілому, так і окремих апаратів входять до іiі складу, таких як тепловий насос або теплоутилізатор. АРМ дозволяє проводити дослідження в автоматичному режимі, що вимагає від дослідника тільки налаштування коректних умов експерименту і його запуск. Результати експерименту будуть автоматично збережені на жорсткому диску комп'ютера.

У статті наведено лише частина експериментів, проведених на даний момент. Вони присвячені дослідженню режимів роботи ТН. Аналізуючи отримані результати можна зробити висновки:

1. Перегрів холодоагенту у випарнику має майже лінійну залежність від положення ТРВ, при збільшенні ступеня відкриття ТРВ перегрів зменшується.

2. Тиск в випарнику і температура кипіння збільшуються при збільшенні ступеня відкриття ЕРВ.

3. Теплова потужність що знімається з випарника збільшується при відкритті ЕРВ;

4. При зміні температури води, що надходить в конденсатор і при незмінній температурі води, що надходить у випарник відбувається зміщення статичної характеристики, однак іiі нахил тобто коефіцієнт передачі об'єкта значно не змінюються;

5. При зміні температури води, що надходить у випарник і при незмінній температурі води на вході в конденсатор відбувається зміщення статичної характеристика і досить суттєва зміна ії нахилу, тобто зміна коефіцієнта передачі об'єкта;

6. При зміні частоти обертання компресора також відбувається тільки зміщення характеристики, без зміни іiі нахилу;

Аналіз результатів експериментів показує, що скоріш за все САР традиційної структури не зможе забезпечити стабільну і безаварійну роботу ТН в широкому діапазоні робочих температур і з максимальною ефективністю. Для забезпечення роботи в таких режимах необхідно розробити САР підвищеної динамічної точності, яка повинна відповідати таким вимогам:

1. Бути інваріантною до збурень у вигляді зміни температури охолоджуючої води на вході випарника $\mathrm{i}$ конденсатора і продуктивності компресора. Це завдання може бути реалізована за рахунок введення до складу САР коригувальних зв'язків, що виконують зсув керуючого впливу. 
2. Мати можливість адаптації до зміни коефіцієнта передачі по каналу керуючого впливу, при зміні температури води на вході випарника [10].

Після рішення цих задач для стабілізації рівня перегріву на мінімально можливому рівні, що відповідає найбільш ефективному режиму доцільно реалізувати в складі САУ функцію гарантування мінімально можливого перегріву, тобто гарантованого, з наперед заданою вірогідністю дотримання обмежень, встановлених регламентами [8].

Дані висновки необхідно враховувати при розробці системи автоматичного управління (САУ) тепловим насосом і системою утилізації тепла ПВС в цілому. Звичайно, для розробки повноцінної САУ необхідно провести ще додаткові дослідження, зокрема дослідження режимів роботи теплоутилизатора.

\section{Перелік використаних джерел}

[1] Сухоцкий А. Б. Вторичные энергетические ресурсы. - 2014.

[2] Жовмір М.М. Утилізація низькотемпературної теплоти продуктів згорання палив за допомогою теплових насосів // Промышленная теплотехника. — 2008. — Т. 30, № 2. — С. 90-98. — Бібліогр.: 10 назв. — укр.

[3] Использование теплоты конденсата «глухого» пара и теплоты паровоздушной смеси [Електронний ресурс] Режим доступу до ресурсу: http://studbooks.net/1897332/

[4] Ефимов А. В., Гончаренко А. Л., Гончаренко А. В. Система глубокой утилизации теплоты газов, уходящих из котельных агрегатов. - 2013.

[5] Kovalchuk D., Mazur A., Hudz S. The model for power efficiency assessment of condensation heating installations //Автоматизація технологічних та бізнес-процесів. - 2017. - Т. 9. - №. 3.

[6] Ковальчук Д. А., Мазур О. В., Гудзь С. С. Оценка энергетической эффективности газового конденсационного водогрейного котла как объекта управления //Наукові праці ОНАХТ. - 2017. - Т. 80. - №. 2.

[7] Ротов П. В. и др. Повышение эффективности работы централизованных систем теплоснабжения за счет применения теплонасосных установок //Промышленная энергетика. - 2014. - №. 7. - С. 27-31.

[8] Петрикеева Н. А. и др. Использование полной теплоты сгорания топлива в котельных установках //Научный журнал. Инженерные системы и сооружения. - 2014. - Т. 2. - №. 4. - С. 76.

[9] Хобин В. А. Системы гарантирующего управления технологическими агрегатами: основы теории, практика применения //Одесса: ТЕС. - 2008. - Т. 306.

[10]Жук А. Ю. Адаптивные системы управления //Молодежный научно-технический вестник. - 2013. - №. 5. - С. 24-24.

[11]Ибраев А. М. и др. Анализ энергетических потерь парокомпрессионной холодильной машины, связанных с процессом перегрева рабочего тела в испарителе //Вестник Казанского технологического университета. 2013. - T. 16. - №. 21.

\section{References}

[1] A. B. Suhotskiy, "Vtorichnyie energeticheskie resursyi", 2014.

[2] ZhovmIr M.M., "UtilIzatsIya nizkotemperaturnoyi teploti produktiv zgorannya paliv za dopomogoyu teplovih nasosIv" in Promyishlennaya teplotehnika, vol. 30, no. 2, pp. 90-98, 2008.

[3] Ispolzovanie teplotyi kondensata «gluhogo» para i teplotyi parovozdushnoy smesi [Online]. Available at: http://studbooks.net/1897332/

[4] A. V.Efimov [A. V. Efimov, A. L. Goncharenko], "Sistema glubokoy utilizatsii teplotyi gazov, uhodyaschih iz kotelnyih agregatov", 2013.

[5] D.A. Kovalchuk [D. A. Kovalchuk, A. V. Mazur, S. S. Hudz], "The model for power efficiency assessment of condensation heating installations" in AvtomatizatsIya tehnologIchnih ta bIznes-protsesIv, vol. 9, no. 3, 2017

[6] D.A. Kovalchuk [D. A. Kovalchuk, A. V. Mazur, S. S. Hudz], "Otsenka energeticheskoy effektivnosti gazovogo kondensatsionnogo vodogreynogo kotla kak ob'ekta upravleniya” in Naukovi pratsi ONAHT, vol. 80, no. 2, 2017.

[7] P. V Rotov [P. V Rotov et al], "Povyishenie effektivnosti rabotyi tsentralizovannyih sistem teplosnabzheniya za schet primeneniya teplonasosnyih ustanovok" in Promyishlennaya energetika, no. 7, pp. 27-31, 2014.

[8] N. A. Petrikeeva [N. A. Petrikeeva et al], "Ispolzovanie polnoy teplotyi sgoraniya topliva v kotelnyih ustanovkah" in Nauchnyiy zhurnal. Inzhenernyie sistemyi i sooruzheniya, vol. 2, no. 4, p. 76, 2014.

[9] V. A. Hobin, "Sistemyi garantiruyuschego upravleniya tehnologicheskimi agregatami: osnovyi teorii, praktika primeneniya" in Odessa: TES, vol. 306, 2008.

[10]A. Yu. Zhuk, "Adaptivnyie sistemyi upravleniya” in Molodezhnyiy nauchno-tehnicheskiy vestnik, no. 5, p. 24-24, 2013.

[11]A. M.Ibraev [A. M.Ibraev et al], "Analiz energeticheskih poter parokompressionnoy holodilnoy mashinyi, svyazannyih s protsessom peregreva rabochego tela $\mathrm{v}$ isparitele" in Vestnik Kazanskogo tehnologicheskogo universiteta, vol. 16, no. 21, 2013. 